\title{
From Learning to Use Towards Learning to Code: Twenty-Five Years of Computing in Dutch Schools
}

\author{
Jan Lepeltak \\ The Netherlands \\ j.lepel tak@learningfocus.nl
}

\begin{abstract}
In the mid-nineteen eighties of last century computers in the Netherlands were broadly introduced in secondary education, and a few years later also in elementary schools. As described in Lepeltak (2006) [1] there has been for the past 25 years a development from learning to use ICT towards using ICT to learn. Learning to use is in terms of being able to operate the machine and its basic applications. Using to learn was focused on using ICT in learning processes for various subject areas. Since 2010 the focus has been slowly moving to the creative, explorative use of ICT. This goes along with the current concept of coding. In the Netherlands coding has not a formal status in education only in the optional subject of information science ('informatica') in upper secondary school. When coding, nowadays mainly practiced by young people outside school, will become a permanent activity is hard to say. There is a strong lobby by the Dutch Royal Academy of Science (KNAW) and industry. Coding in relation to robotics has a lot of potential. It is active, exploring pedagogy and its relations with technology, biology, science. Coding provides schools with a lot of opportunities within the curriculum.
\end{abstract}

Keywords: Netherlands, using computers, coding.

\section{A Short History of Educational Computing}

A survey in the Netherlands in 2005 [2] showed that in secondary education (from 1218 years), $47 \%$ of the Dutch teachers use ICT in their lessons. What we see is a very slow growth in the use of computers in the learning process within the schools. In $200266 \%$ of the interviewed teachers expected that they would use ICT within three years. From a 2013 survey we learned that in fact $50 \%$ of the teachers actually used digital content in their lessons [3]. It seems almost as if the use of ICT is slowing down in secondary education in the Netherlands.

It is not the availability of hardware or the access to the internet which is holding them back. Is it the software? Or has it to do with the training and the professional development of teachers? Nevertheless about $64 \%$ of the Dutch teachers feel selfconfident enough to use computers in their classroom [4]. In 2012 the use of ICT in schools shows an increase.

In primary and secondary education about $78 \%$ of the primary school teachers' use on a daily or weekly basis learning supported software, very often combined with a 


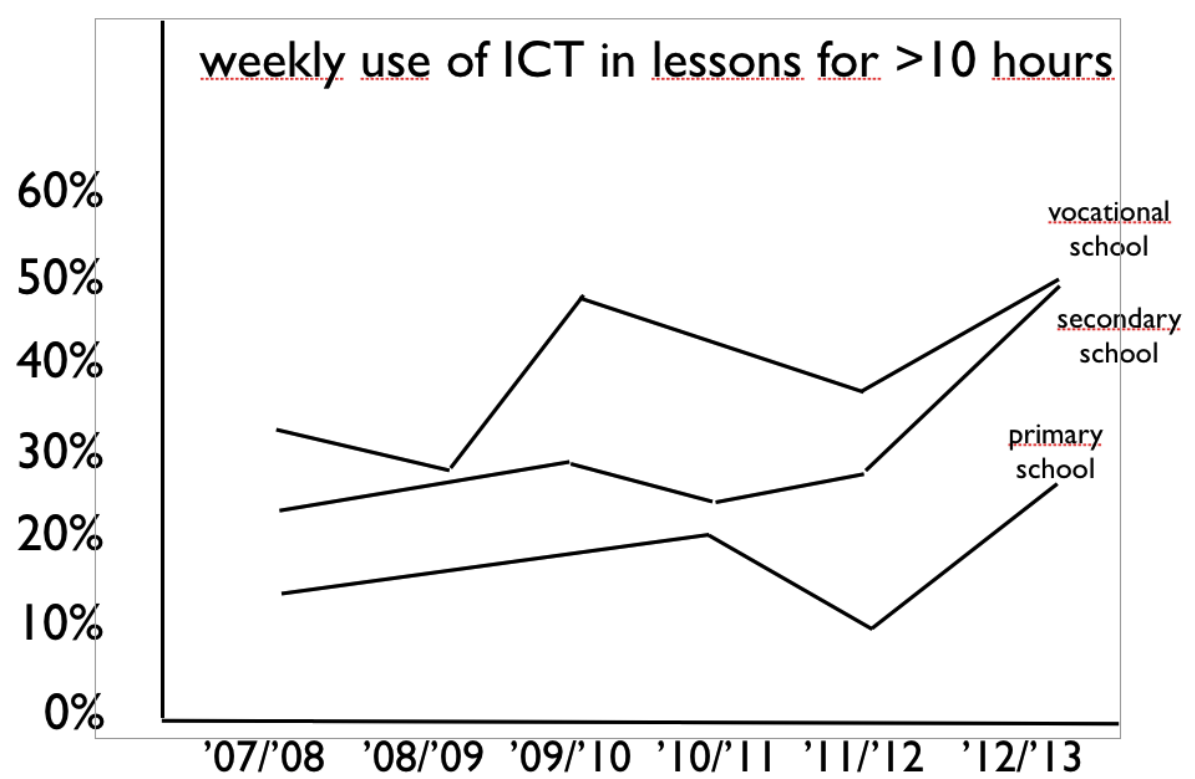

traditional method/schoolbook. In the graph below we see the percentage of teachers in the various school types that use ICT content in their lessons.

The lowest line represents the use of ICT by teachers in primary education (4-12 years), the middle one represent secondary education (12-18 years) and the above line represents vocational education (14-18 years). After a downfall in 2011 the use of ICT shows an increase. The use of internet is not taken account of in this graph. $80 \%$ of the teachers use internet on a daily basis.

Schools for secondary education started in 1984 with a new experimental subject area called 'civil information science' (burgerinformatica) a project for students from 12 - 16 years. The National Institute for Curriculum Development coordinated the project. The curriculum combined computer awareness and computer literacy. Its main purpose was: "The development of knowledge and skills that makes it possible for students to react adequately in situations where the use of data-processing systems is possible or necessary. Students should also be able to make critical evaluations of the social implications and impact of the use of such systems." [5] On the basis of rather generic goals four areas for learning were identified.

1. Use of applications

2. The social implications

3. Problem analysis and programming

4. Building principles ('architecture') of hard- and software

After a large school reform in the Netherlands in 1993 Informatiekunde (the new name for an introduction in computing and informatics) became a school subject with a curriculum of 80 hours. However it was practiced for only 20 and 40 hours on the 
school timetable. The Dutch school inspectors also claim in a report [6] that this is not enough to make this a serious subject within the curriculum. The National institute for Curriculum Development developed the core objectives for this subject area with the long term objective of integrating these 'learning to use skills' in the regular subject areas (maths, language and sciences).

A strong lobby for the Apple approach started, without success. In 1990 Bill Gates signed in the Amsterdam Hilton a Windows contract with the Dutch government to supply elementary schools with a special MS-DOS computer named the Comeniuscomputer, after the famous $17^{\text {th }}$ century Tsjechian philosopher and pedagogue Jan Amos Comenius. It was installed with the new Windows interface.

In 1985 the MS-DOS personal computer (PC) was introduced in secondary education in the Netherlands. With its command driven interface the PC was not an easy tool to handle.

In 1984 Apple introduced the first PC with a graphic interface for the consumer and small business market. It formed the basis of modern personal computing. "The Mac's elegant system software was its great accomplishment. It displayed a combination of aesthetic beauty and practical engineering that is extremely rare" [7] wrote Paul Ceruzzi in his history of modern computing.

The choice was made on the basis of a report from the Centre for Education and Information at Twente University. Although the cost aspect played a role as well, the main argument for not choosing the Apple Macintosh line was the fact that only one company manufactured them. [8]

Ironically we see in 2013 a strong but controversial movement about building elementary school education around the use of an iPad. The first so called Steve Jobs school opened in august 2013 with a lot of (inter)national publicity. Apart from this we notice a lobby for the introduction of coding and programming in elementary schools.

\section{$2 \quad$ Hard and Software in the $21^{\text {st }}$ Century}

The schools in the Netherlands, like most northern European schools, are nowadays well equipped with hard and software. In 2012 the ratio pupil: device (desktop, tablet, laptop) in Dutch elementary schools is 1:5. In secondary education it is 1:4.9 and in vocational schools 1:5.7 [9].

In recent years educational publishers in the Netherlands produced almost no schoolbooks without any software. The part of printed content is diminishing. For the past five years several large and well known publishing houses merged and were sometimes taken over by hedge funds.

What is left is a small number of well-known educational publishing companies in the Netherlands. In 2013 these firms developed together with other players (e.g. school material distributors), a single login portal named basispoort (http://info. basispoort.nl/) which gives access to their digital content.

Because of the monopoly of the educational publishers, school managers complain that they are obliged to buy a school license. This combined with a lot of technical problems during the start in September 2013 made things worse.

Since 2005 schoolbooks in secondary education are free. Schools get a special budget for every student. This makes it very interesting for schools to develop their own content. There is a strong open source and open content movement in the 
Netherlands. They promote the use of free content on the basis of a wiki-concept called Wikiwijs (say 'Wikewise'). But the complete free exchange of content seemed too idealistic. Nowadays schools can subscribe to meta-tagged content and arrange their own curriculum content.

The budget for free schoolbooks is part of the lump sum (€7500) that secondary schools receive for every student. This enables school administrators to develop their own policy for using, buying or developing learning material. According to the national council for secondary schools (VO-raad) this will make it easier for schools to change from analogue, printed content towards digital content and lesson material. It could make it also easier to make more personalized learning possible. For free schoolbooks the secondary schools receive $€ 321.50$ a pupil. For most schools this is not sufficient. Parents have to pay an extra contribution for digital material or licenses that give access to educational databases of publishing companies or Wikiwijs.

In the Netherlands there is not a national curriculum as for example in England. But pupils (also very young ones) are more and more tested. In primary education there are several tests obliged. The primary school ends with a national school test at the age of 12. At the end of secondary education there is a final national examination. Although there is no national curriculum for primary education and general secondary education, certain objectives are formulated. The situation in vocational education is more complex. Although there is not a national curriculum it doesn't mean that schools develop their own curricula. The authors of schoolbooks develop on the basis of curriculum examples most of the curricula. The majority of the schoolbooks are more or less traditional in their pedagogy. This implies that they are course driven. They have an instructional character. ICT comes with it as an asset. Educational publishers are willing to develop more innovative material which differs from the so called book plus production (traditional course with some software). They claim that the majority (70\%) of the market asks for 'traditional' material in 2005. Recent surveys show that the majority of the teachers still use traditional schoolbooks although they all have strong digital component. [10]

\section{Informatics, Computing, Critical Skills and Coding}

Despite the fact that every school in the Netherlands has a free broadband connection with the internet, the existence of a national educational network (kennisnet) and an average pupil-computer ratio of 9:1 in elementary and secondary education, [11] educational use in secondary education is below expectation.

We consider learning to be more effective if it is perceived to be meaningful and embedded in authentic situations. [12] It is in what we now call the social constructivist approach of Lev Vygotsky where we find a great emphasis on the importance of interaction between people (children, teachers, parents) in cognitive development. Situated learning - anchoring instruction in real life problems that have to be solved and creating rich environments that stimulate learners to interact about real life problems is becoming more and more mainstream in the use of ICT for learning. [13] By situated learning we mean the physical and social context within which learning takes place. This remains an integral part of that which is being learned [14]. This is hardly the case in the traditional technology-driven courses where one is supposed to learn to work with software applications in an isolated way. Children learn to use word 
processers by learning to express themselves by writing, learning to use spreadsheets by e.g. during statistic research in their environment and by learning to use creative tools and mind maps by exploring their creativity.

What we learn from the Dutch situation is that it is difficult to change patterns that have been followed for years. In countries where ICT has been recently introduced we could learn from new approaches by action research methods and the exchange of free open source material. Education should primarily be a matter of students, pupils, teachers and parents. The involvement of large soft- and hardware companies is not automatically a benefit for the development of school systems with ICT. Teachers in secondary schools are subject oriented i.e. they are teaching maths, language, physics, history etc. It is for this reason that success lies only in the development of concrete plans and projects for the use of ICT that is integrated in their subject areas and in all their teaching. This is why in physics teaching in the Netherlands, where there is a longstanding tradition in the use of science labs, ICT is well integrated in the curriculum. From the beginning in the 1980s tools like IP-Coach and coachlab, were introduced to support the modern teaching of physics. But a new generation of tools is developed e.g. VinciLab an advanced educational data logger for measuring and simulation, available since autumn 2013 [15].

The arrival of a new generation of young teachers is giving a boost to the use of ICT and the development of the so called $21^{\text {st }}$ century skills. They use social media and they organize successful informal meetings like Edcamps.

\section{New Technologies in the Classrooms: The Digital Whiteboard}

The first digital whiteboards (DWB) were introduced in Dutch schools in 2002. In 2006 one could find a digital whiteboard in $10 \%$ of the elementary schools. [16]. Most of the time the DWB was used for instruction and presentation by teachers. But we see nowadays a growing amount of use by pupils.

The introduction of DWB was criticized. Many educational innovators feared that the DWB would support the traditional instructional approach in the classroom. The Institute for Education and Communication of the NHL-University for Applied Science in Leeuwarden organized in 2006 a seminar about the educational use of digital whiteboards in elementary schools. The emphasis during the seminar was on the use of the digital whiteboards by pupils. Dughall McCormick, a British educational expert, showed examples of the creative use of digital whiteboards by pupils at this seminar.

At this moment about $40 \%$ of the classrooms in The Netherlands are equipped with digital whiteboards. In the US this is around 15\%, Germany 5\% and France $2 \%$. Only the UK is far ahead with a penetration of about $70 \%$.

The presence of a DWB doesn't mean that it is used differently from the traditional blackboard in using it only as a beamer showing/exploring the internet. In a report from a Dutch television youth panel in $201358 \%$ of the pupils say that their teachers don't use their DWB appropriately [17]. 
Worldwide or even national statistics on whiteboard penetration in classrooms are difficult to gather, but one survey of about 1,400 full-time teachers in the United States found that $59 \%$ of respondents said whiteboards were available in their schools, with $36 \%$ saying they had access in their own classrooms. Penetration in the United Kingdom is as we saw far higher, with the government having directed funding for whiteboard purchases at virtually every public school and in most classrooms during the past decade. A recent OECD report shows comparable figures about the penetration. [18] Remarkable are the differences within the EU. The total number of classrooms (teaching spaces) in each country is given in parentheses.

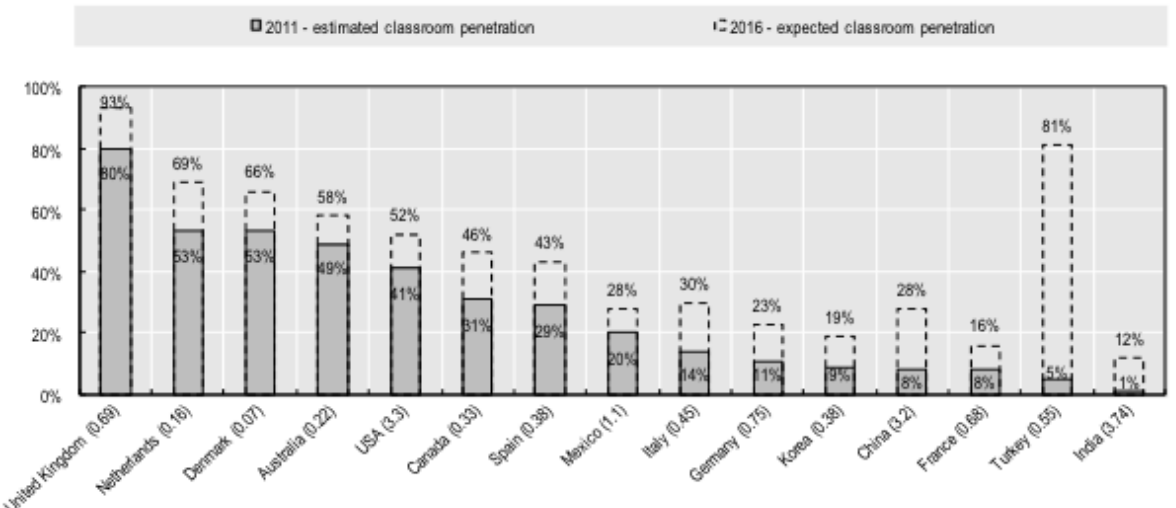

Source: Futuresource Consulting (2012) cited in the OECD report.

The OECD in their report concluded as follows. They use the term Interactive Digital White Board (IWB) instead of DWB:

1. First, IWBs as such have no transformative power on pedagogy. Teachers' diverse beliefs about pedagogy and student learning, their preferred uses of conventional boards, their goals and their prior experiences, shape the way in which they use all educational tools, including the IWB. New approaches can be developed if supported by adequate investments in professional development, but not imposed.

2. Second, professional learning about IWBs and their effective use takes time. Pedagogical change only comes with significant investment in professional development and is generally only observed after at least one year of full-time use by teachers.

3. Third, because their impact on pupils is mediated by their use by teachers, there are no robust, clear-cut positive effects on pupil learning associated with IWBs as such: the context and the nature of use of IWBs are all-important. Nevertheless, effects on learner achievement attributed to IWBs are generally more positive than for all other forms of technology. 


\section{$5 \quad$ New Trends: Social Media and Coding}

In spring 2013 the second conference on social media in education took place in the just opened Eye-film Institute at the Amsterdam harbor front. The use of social media as an educational tool is rather new and its use is not very widespread. Social media in the schools is a big issue in terms of safety, privacy and protection. Serious incidents concerning cyber bullying, harassment, threats and grooming also took place in the Netherlands.

The use of smart phones by pupils is widespread. $60 \%$ of the children from 8 to 12 years have a mobile phone [19]. In schools, teachers and various organizations are trying to make their pupils and their parents more aware of the potential dangers that exist when one is using social media such as Facebook, Skype, Twitter etc. A growing number of schools is now using a protocol for the use of mobile phones of their pupils. Schools forbid the use of mobiles during school time or on the school premises.

About the educational use of social media within Dutch schools not much research is yet available. One could say that the use of social media is widespread within the group teachers that are early adopters of technology. More than 200 active educational bloggers ('edubloggers') are active in The Netherland. They form a community of teachers, researchers, parents, journalists, developers, publishers etc. This community is one of the leading informal groups in ICT innovation and education in the Netherlands.

A very interesting eScience [20] project at Radboud University (Nijmegen) and the Netherlands eScience Centre (Amsterdam) in Twitter is TwiNL. It provides a large database with all the daily tweets in the Netherlands, with anonymous time and location information. The database is freely accessible. Physicist as well linguist, sociologist, epidemiologists already use this D-base for research. [21]

\section{Revival of Coding?}

European business and industry are promoting coding in education, since ICT-experts are shortcoming now and in the near future. For The Netherlands the shortage for the forthcoming years is estimated between the 6.000 and 40.000 professionals. Depending on how the economy develops. [22]

In the Netherlands there is traditionally a large emphasis on digital literacy. It was the Dutch Royal Academy of Science (KNAW) which wrote a report for the Dutch government about ICT, programming and digital literacy. Digital literacy refers to the ability to make prudent use of digital information and communication, and to evaluate the consequences of that use critically. In the $21^{\text {st }}$ century digital literacy belongs to the basic skills of every educated person in the KNAW states. It is necessary for navigating through the information society. Like language and mathematics skills, digital literacy requires instruction and education over a longer period of time. It should therefore be covered in our education system.

The KNAW reports that the relevant school subjects are below standard and do not prepare pupils for the information society. It is urgent for the government to revise 
current teaching of digital information and communication in secondary schools. If not the Netherlands will be behind similar countries. Our leading position as a knowledge and innovation economy will be at risk. At general secondary (havo) and preuniversity (vwo) levels the subjects information science and informatics had in 2013 a marginal status. Their quality is insufficient and their content is outdated. Urgent action is needed, the KNAW claims.

In developing its views the Netherlands is neither in the vanguard nor in the rear guard. The challenge is to move beyond discussion and take action, as similar countries are doing. The Academy recommends that the relevant part of secondary education is redesigned from the ground up. We must give digital literacy our ongoing attention, first offering pupils a sound common basis and then allowing for an individual and in-depth study.

The Academy made five recommendations to the Minister of Education, Culture and Science:

1. Introduce a new compulsory subject Information \& Communication in the lower years of havo and vwo. This should be a broad and compact introductory subject, covering the essential facets of digital literacy.

2. Completely overhaul the optional subject Informatics in the upper years of havo and vwo. By a flexible and modular design, the subject should remain up to date and appeal to pupils regardless of their focus area.

3. Encourage interaction between these subjects and other school subjects.

4. Make it a priority to raise a new generation of teachers with new skills and attitudes. Instruct the schools for higher professional education (hbo) and the universities to collaborate in this regard.

5. Promote instruction in digital literacy, in coordination with the initiatives taken by the Minister of Education, Culture and Science. This will help in achieving the aims of your ICT policy (Digitale Agenda.nl). The Academy's report focuses on havo and vwo, the sectors of secondary education with which it is most concerned. It is beyond question, however, that digital literacy is equally important in pre-vocational (vmbo) and primary education. Each of these needs a separate set of recommendations, to be formulated by organizations that are involved.

Because of the involved political and legislative discussions the adoption of these recommendations the implementation will take at least several years.

In the meantime, in 2013 international initiatives are under way. So we see that The Council of European Professional Informatics Societies (CEPIS), a non-profit organization seeking to improve and promote a high standard among informatics professionals in recognition of the impact that Informatics has on employment, business and society. CEPIS represents 35 Member Societies in 32 countries across greater Europe. The decline of computing/coding in education seems a western problem. US students already significantly lag their global counterparts where maths and science skills are concerned. But computer science is in even worse shape: Of 12 technical subjects examined in a recent study by the National Centre for Education Statistics, computer science was the only one that declined in student popularity from 1990 to 2009 [23]. 
CEPIS started in 2013 a lobby with the EU-commission to stimulate coding in elementary and secondary schools in Europe. Meanwhile in England we see since 2012 a strong pressure from the government. Lessons about ICT should be replaced by lessons about coding. This is a policy that seems to be controversial because of the increasing influence of industry on the national curriculum.

\section{$7 \quad$ New Trends and Initiatives}

In the Netherlands all kind of non-formal initiatives are manifest. In 2013 the World Robocup Junior was organized in the city of Eindhoven. This very successful competition got a lot of (international) media coverage. More than a 1000 youngsters from 8-18 originating from more than 30 counties were in competition for about a week in Eindhoven.

In the Netherlands one also notices various local initiatives. For example workshops are provided in elementary schools in making your own app or game. Because of the lack of knowledge and experience at elementary schools these workshops are organized at an ad hoc level.

In the Netherlands about $14 \%$ of the teachers in elementary schools are men. Other European countries show a similar development. [24] Male instructors resign after a few years of teaching [25]. $25 \%$ of men leave the teaching profession in elementary school after four years.

Because of the criticism of the quality of teacher training in 2010 some universities established so called renewed training institutions called the Academic Pabos. They maintain specific admission standards and a more academic curriculum inspired by the way teachers are trained in Finland.

Since 2011 the policy of the Dutch Ministry of Education is focused on promoting technology in the elementary schools. The participation of women in beta-studies is significantly less than that of men. The ambition is that in 2020 science and technology will be part of the elementary school curriculum - a challenge for the existing teacher training centres.

Several initiatives are often from women who worked in the IT-industry and are now giving workshops in elementary schools.

There is a group called Codekinderen (Codekids) that gives pupils in groups 3 to 8 of primary school the chance to discover their digital talents. In workshops the children are introduced to the media they use every day.

There is also an international network of 27 countries of clubs that focus on coding called CoderDoyo. In the Netherlands there are three clubs (Amsterdam, Rotterdam and The Hague) in which children e.g. develop games. These activities take place outside the school.

Strong open source programming languages like Scratch, developed by MIT-media lab, are available for free.

The new Mindstorms EV3 robotic platform makes it possible for children to build very powerful robots. Scratch can be used as a programming language for the first and second generation of Mindstorm Robotics platforms but not for the EV3 in due time, because of its different architecture. 
In general one can say that we see several initiatives most of them that take place outside the school and school hours. In the elementary school the focus is on technology and science and not as much on ICT and coding.

In secondary education we see that the position of informatics is rather difficult because of the following reasons:

1. Shortage of qualified teachers

2. Low status. It's a subject that can be offered on a voluntary basis but is not mandatory

3. It is not part of the central examinations

4. There is no overview of the number of pupils and schools that offer information science

In the UK the government made coding a mandatory subject of the curriculum. The plans are controversial. The criticism in the educational social media like the Mirandenet is that these days industry (Microsoft and Cisco) seem to determine part of the computing curriculum.

In October 2013 a new BBC Director General announced an ambitious nationwide technology initiative to encourage the public to take up computer programming. The education secretary Michael Gove's ambition is to revolutionize learning in England's schools. One will see five-year-olds studying fractions and writing computer programs in their first year of school, according to final versions of the new national curriculum. [26] From age seven, the new curriculum says, children should be taught computer-aided design, and from 11 they will learn 3D and mathematical modelling, as well as using computer-aided manufacturing tools and including programmable components in design. UK government wants to implement the new curriculum in September 2014. It is not clear if there are enough qualified teachers.

The Dutch government hardly supports coding unless it is part of science and technology in the elementary school or as part of information science (an optional subject). It's a course that a lot of secondary schools don't offer. The Dutch school system does not have a national curriculum, as mentioned earlier. There are only core objectives stated. By testing and central examinations the school inspection is monitoring schools for their results. The challenge for 2014 and further will be 1) to introduce coding in schools and 2) to get coding on the political agenda. Serious experiments with coding in elementary and secondary education should be explored.

\section{References}

[1] Lepeltak, J.: From learning to Use Towards using to Learn. About lessons to be learned from ICT-education in the Netherlands. In: History of Computing and Education 2. Springer, New York (2006)

[2] TNS NIPO onderzoek ['research'] in opdracht van St.Ict op school (Januari 2006)

[3] Vier in balans monitor 2013. De laatste stand van zaken van ict en onderwijs. Kennisnet, Zoetermeer (2013)

[4] Vier in balans monitor 2013. De laatste stand van zaken van ict en onderwijs, p. 37. Kennisnet, Zoetermeer (2013) 
[5] Raamwerk ['framework'] Burgerinformatica. Stichting voor leerplanontwikkeling. Enschede (1983)

[6] See also note 3

[7] Ceruzzi, P.E.: A history of modern computing, pp. 273-276. MIT Press, Cambridge (1998)

[8] Schoenmaker, J.: Apparatuur en besturingssystemen voor het basisonderwijs. COI, Enschede (1987)

[9] Vier in balans monitor 2013. De laatste stand van zaken van ict en onderwijs, p. 42. Kennisnet, Zoetermeer (2013)

[10] See ICT in the Netherlands. Fact and figures 2003-2004. IVA/ITS Ni-jmegen/Tilburg (2004), http: / / www. ict-onderwijsmonitor.nl/

[11] See note v

[12] Bereiter, C.: Education and mind in the knowledge age. New Jersey LEA Publishers, Mahwah (2002)

[13] Maddux, C.D., Lamont Johnson, D., Willis, J.W.: Educational Computing. Learning with Tomorrow's Technologies, 2nd edn., Boston (1997)

[14] Wood, D.: How children think and learn. The social contexts of cognitive development, 2nd edn., London (2005)

[15] See also http: / / cma-science.nl/support/vincilab/index.html

[16] ten Brummelhuis, A.: Digitale schoolborden in het PO. Onderzoek naar implementatie, gebruik en meerwaarde van digiborden in het primair onderwijs, Zoetermeer (2008)

[17] See, http://1vjongerenpanel. eenvandaag.nl/

[18] Hennessy, S., London, L.: Learning from international experiences with interactive whiteboards: The role of professional development in integrating the technology. OECD - Working Paper 89 (2013)

[19] see, http://www.gsminfo.nl/blog/nieuws/4282/zestig-procentbasischoolkinderen-heeft-gsm-wat-zijn-kindvriendelijkesmartphones

[20] eScience combines big data analysis and modelling with the use of supercomputers for research in various disciplines

[21] the website is, http://twiqs.nl/; a short video (English) about this project is available, http: / / www . youtube.com/watch?v=ZRUpdUiOGVE

[22] The prognostic figures differ but lie between the 6000 end 40.000 depending on the job level and the economic development

[23] Report USA Ministerie of education (2011), http://nces.ed.gov/nationsreportcard/pdf/studies/2011462.pdf

[24] Feminisering van het primair onderwijs (the feminization of elementary education) CAOP-report (January 2013)

[25] Vakkundig meesterschap en meesterlijk vakmanschap Wim van de Grift, Michelle Helms-Lorenz, Dik Maandag \& Siebrich de Vries Groningen (2012)

[26] See the Guardian (July 8, 2013) 